"Seeing in the Dark"

\title{
The Aesthetics of Disappearance and Remembrance in the Work of Alberto Rey
}

\begin{abstract}
This article examines how contemporary Cuban American artists have experimented with visual languages of trauma to construct an intergenerational memory about the losses of exile and migration. It considers the work of artist Alberto Rey, and his layering of individual loss onto other, traumatic episodes in the history of the Cuban diaspora. In the series Las Balsas (The Rafts, 1995-99), Rey explores the impact of the balsero (rafter) crisis of 1994 by transforming objects left behind by Cuban rafters on their sometimes ill-fated journeys to the United States into commemorative relics. By playing on a memory of absence and the misplacement of objects found along the migration route of the Florida Straits, Rey's visual language transmits the memory of grief across time, space and generational divides. Rey's visual strategies are part of an "extended memory" tied to the aesthetics of disappearance and remembrance in contemporary Cuban American art. His use of objects as powerful memory texts that serve to bring fragmented autobiographical, family, and intergenerational testimonies of loss together, suggests how visual artists can provide us with more collective, participatory and redemptive models of memory work.
\end{abstract}


Trauma, and the traumatic experiences that generate trauma, often defy representation. Literary scholar Cathy Caruth argues that "the most direct seeing of a violent event may occur as an absolute inability to know it." ${ }^{1}$ Traumatic memories do not fit easily into a singular framework of understanding: as fragments replayed over time and often "belatedly," traumatic memories are experienced and communicated invariably through the senses, as affective or sense memories, rather than as acts that are spoken or narrated in an orderly or linear fashion. ${ }^{2}$ The nature of traumatic memory draws our attention to the ways in which conventional forms of representation often fail to "describe the indescribable."3 This "inability to know" is compounded when records of traumatic events are absent in the textual archive and when the voices of witnesses are either missing or repressed.

In her study of protests by families of those who have "disappeared" through political violence in Latin America, Diana Taylor identifies performance as a critical vehicle for communicating traumatic memory across the generations, especially in the absence of written archives. Taylor's conceptualization of the "repertoire" (as opposed to the textual "archive") underscores the importance of embodied practice and visual culture for bringing memory and alternative visions of history into view. ${ }^{4}$ Scholars in art history and the fields of performance studies, memory studies, and cultural geography have demonstrated how visual artists can inform our understanding of traumatic memory and its representation, for example, by illuminating ways in which grief and loss are witnessed, performed and embedded in our "everyday" lives, and by tying artistic practice to new forms of historical knowledge and collective, politicized modes of remembrance. ${ }^{5}$ Art historian Jill Bennett has analysed how "visual languages of trauma" in contemporary art can foster "affective connections" with others who have experienced loss. Doris Salcedo's installations, for example, explore the nature of trauma in relation to those who have "disappeared" in Colombia, by embedding traumatic memory in uninhabited domestic spaces and seemingly mundane objects, such as chairs, tables, 
shoes and clothing, in order to emphasise the missing body. The repetition, misplacement and transfiguration of everyday objects draw our attention to the silence generated by political violence and the loss of loved ones. ${ }^{6}$ The "aesthetics of disappearance"7 in works such as Salcedo's expose how violence removes the physical body as a speaking subject. These practices also relay the disorientating modes of perception attached to trauma and grief, modes that conventional forms of testimony often fail to articulate. Yet as Bennett suggests, these artistic practices can be cathartic and "regenerative," not only in the sense of providing alternative ways of seeing, but by forging links between those who have experienced trauma in different places and at different times. In this process, artists become intermediaries who mesh individual with collective forms of traumatic memory, producing "affective" artworks that enable viewers to participate in a broader "community" of trauma through forms of secondary witnessing and "embodied perception." In order to become productive, then, visual representations of trauma must be "embedded in a deeper, more extended conception of memory," according to Bennett, "one that is not confined to a single point in time but that extends temporally and spatially to engage forms of lived experience."

This discussion considers how visual languages of trauma have helped to build an "extended conception of memory" in contemporary Cuban American art, especially among a generation of artists who left the island as children in the 1960s with few memories of home. It examines the work of artist Alberto Rey in particular, and his mapping of personal loss onto other traumatic episodes in Cuban history. In Las Balsas (The Rafts, 1995-99), Rey explores the human impact of the balsero (rafter) crisis of 1994 through a series of paintings that transform objects left behind by Cuban rafters on their sometimes ill-fated journeys to the United States into commemorative relics. Rey experiments with a language of trauma that marks the work of artists who have used a similar aesthetics of disappearance and recollection to speak about the losses of Operation Pedro Pan, a Catholic, CIA-led anti-Castro programme 
that sought to "rescue" Cuban children from communism during the early 1960s by relocating them to camps, orphanages and foster homes in the United States. By experimenting with the aesthetics of disappearance and recollection to talk about another, later traumatic episode in Cuban history, the balsero crisis, Rey's visual language transmits the memory of grief across time, space and generational divides. Existing scholarship and recent exhibitions have identified a powerful form of exilic memory in Rey's art. ${ }^{9}$ Yet a closer interrogation of his work in dialogue with other second generation artists and historical traumas suggests that his visual strategies are part of an extended memory tied to the aesthetics of disappearance and remembrance in contemporary Cuban American art.

\section{Trauma and memory in Cuban American art}

Literary scholar Román de la Campa has described Cuba as "a disjunctive or severed nation."10 Cuban diaspora memory is equally fractured, not simply because of the political conflict that fragments families between the island and the United States, but because Cubans in the United States have varied social, ethnic and generational backgrounds and different experiences of the homeland-both pre- and post-revolutionary Cuba - and the host country. While the performance of memory nurtures the preservation of the Cuban diaspora, Cuban American critics, writers and artists have experienced difficulty narrating the full complexity and diversity of what remains a fractured memory. Embroiled in national security issues and diplomatic tensions, Cuban diaspora memory has long been “a militarized zone," argues María de los Angeles Torres. ${ }^{11}$

How then, have these ruptured spaces and memories been represented in visual terms? In the 1990s, curators and scholars identified the aesthetics of "fragmentation" in Cuban American art as a critical mode of bearing witness to the losses of exile, family separation, and political violence. In the essay accompanying the 1994 exhibition, Transcending the Borders 
of Memory, Olga Viso suggested that the use of "fragments" united the work of featured artists Ana Mendieta, María Magdalena Campos-Pons, María Brito, and María Martínez-Cañas, despite each having "different memories, as well as voids." 12 The 1993 exhibition, Remnants: Installations by Five Cuban American Artists, which included the work of Brito, also attempted to identify visual languages of trauma. Curator Cris Hassold argued that the remnant in these artists' works evoked "a special poetry that often contains traces of a past nightmare." Expressing the disarticulation associated with trauma, remnants served as powerful "reminders" of absence on multiple fronts, for "in the remnants they gather together," noted Hassold, "[these artists] hold on to a past that they know no longer exists, and hope for a future that they fear may never come."13 Hassold's statement tied the remnant to the act of disappearance. More recently, literary scholar Ricardo L. Ortíz has suggested that the pressure to assimilate, coupled with the very real possibility of never returning to Cuba, generates "an almost obsessive insistence on reproduction" in Cuban American literature and music, a strategy designed to promote the act of "non-disappearance." 14

Prior to the 1990s, the "aesthetics of disappearance" appeared most forcefully in the performance art of Ana Mendieta, whose work featured in Transcending the Borders of Memory nine years after the artist's untimely death in 1985. In 1961, Mendieta arrived in the United States aged twelve through Operation Pedro Pan. The operation brought some 14,000 children to the United States between January 1961 and October 1962; 7,000 of these children were taken into long-term foster care and orphanages. ${ }^{15}$ Mendieta grew up in foster homes and orphanages in Iowa before being reunited with her mother, who arrived via Johnson's "Freedom Flights." Her father remained a political prisoner in Cuba for eighteen years after opposing Castro's Revolution. Mendieta later declared that "all detachment or separation provokes a wound," and she went on to produce her famous Silueta (Silhouette) series between 1973 and $1981 .{ }^{16}$ Mendieta's silhouettes involved the creation of earth-body sculptures in 
which the artist's real body was repeatedly missing at sites in Iowa, Mexico and later on, in Cuba. The imprint of Mendieta's displaced body, a symbol of the deterritorialized subject, was either burnt into the natural landscape with the use of gunpowder, or traced with blood and fire to evoke not just the pain of exile, but also the possibility of healing through rituals associated with Cuban Santería. Art historian Jane Blocker has connected Mendieta's earth-body sculptures to "the aesthetics of disappearance," for not only was the human body absent, but the work itself vanished into ashes or was erased through the natural movements of water and sand. Yet, by experimenting with invisibility, argues Blocker, Mendieta's work underscores what Peggy Phelan has called the "generative possibilities of disappearance." 17 As Mendieta herself suggested, absence can invoke a powerful presence and initiate the remaking of deterritorialized bodies and subjectivities: "I started doing imprints to place myself and my body in the world," explained Mendieta. "That way I can do something, step away from it and see myself there afterwards." ${ }^{18}$ Mendieta's siluetas provide an artistic complement to the acts of reproduction and non-disappearance identified by Ricardo Ortíz in Cuban American literary and musical expression.

One of Mendieta's female compatriots was the sculptor María Brito, who also arrived in the United States via Pedro Pan in 1961. Employing objects in lieu of human subjects, Brito's installations from the 1980s and 1990s tied the fragments of familial loss —often in the form of household furniture items - to uninhabited domestic spaces, as in Come Play with Us: Childhood Memories (1984) and Merely a Player (1993). ${ }^{19}$ For Brito, as for Mendieta, the losses of Pedro Pan and relocation to a camp in Dade County, Florida, could be articulated only through the aesthetics of disappearance and fragmentation. "A lot of the memories from that time, as important as they are to my life, have blurred. I have gaps in my memory, so it must have been quite painful. Today, I can only look back and see the pain in a very objective way," 
explained Brito in 2004, whose object-based installations attempt to translate this pain into tangible rather than ephemeral forms. ${ }^{20}$

Brito's work reflects the very real difficulties of articulating the trauma associated with Operation Pedro Pan. Historian Karen Dubinsky claims that Pedro Pan children became "global icons of adult political dilemmas" during the 1960s, and "mute symbols of an extraordinarily stark conflict between nations." ${ }^{21}$ Even when this generation began to mature from the 1970s onwards, there was a distinct absence of scholarly and testimonial projects about the impact of Pedro Pan. On his arrival in the United States as a child, Román de la Campa was placed in a camp in Jacksonville, Florida, which he described as akin to a "penal colony." Campa also underscored the silence about Pedro Pan: "Our exile condition was hardly ever discussed; neither was our national predicament, nor the family separation we were all enduring." Political tensions and the propagandist language of two different national governments compounded the inability to speak about Pedro Pan. ${ }^{22}$ As a child of Pedro Pan, María de los Angeles Torres claimed these experiences were "confined in such a closed context, faded into a repressed collective memory, to be recalled only by a political rhetoric that resisted ambivalence or contradictions that portrayed our flight as a tale of heroism. Thus, while we could readily recount the factual episode of our early migration from Cuba, the emotional travails and complexities were now inaccessible." Indeed, perhaps Ana Mendieta referenced the same "repressed collective memory" described by Torres when she claimed that "all art comes out of sublimated rage."23

In the 1990s, artist Ernesto Pujol followed in Mendieta's footsteps and supplemented Brito's installations by tapping into the memory of Pedro Pan as a panacea for his own dislocation. Born in 1957, Pujol left Cuba for Puerto Rico when he was four years of age. He arrived in the United States in 1979, long after Pedro Pan had ended, but with memories of childhood loss. Pujol dedicated his multi-room installation, The Children of Peter Pan (1995), 
which was shown at the Casa de las Américas, Havana, to Ana Mendieta. In his earlier work, Pujol experimented with the repetition of silhouettes in painted form, mimicking the way that Mendieta reproduced her own disappearing form again and again in the natural landscape. Pujol continued to explore the act of disappearance by developing a language of trauma similar to that of Brito. In The Children of Peter Pan, he tied found objects - clocks, suitcases, shoes, cradles, and household furniture, including rocking chairs, wardrobes full of clothes, and beds - to family narratives and abandoned domestic spaces. In the final part of his installation, entitled "Flight," thirty-four white shirts belonging to children of ages similar to those who left during Pedro Pan were suspended eerily above a traced outline map of Cuba. ${ }^{24}$ Viewing his work as "perform[ing] an archaeology of memory," Pujol has explored what he calls "the history that objects silently carry and the memories they trigger," since objects are "often the only remaining witnesses to people's lives." Pujol describes his memory work as a form of "obsessive memory." If this "obsessive memory" enacts a mode of repetition akin to the "reproduction" found in Cuban American literature and the duplication of Mendieta's siluetas, it also seeks to incorporate what Pujol calls the "iconography generated by families and individuals across the generations" [my emphasis]. ${ }^{25}$ This extended, intergenerational memory, the tying of one's own memories to those of others through a language of trauma, is enacted spatially as much as temporally, especially in cases where traumatic experiences distort or suspend a sense of time, a process illuminated by Pujol's first installation room, "Time Passes On," in which several clocks are deliberately misaligned.

The emphasis on the missing body, repetition, and the transformation of found objects into memory texts suggests that the aesthetics of disappearance became manifest in distinct and often spatialized ways among an artistic generation that left Cuba as children in the 1960s. For Mendieta, memory work was enacted in and through the natural landscape; for Brito and Pujol, the domestic space became the prime site of memory work. Memory studies scholar Aleida 
Assmann suggests that "places themselves may become the agents and bearers of memory, endowed with a mnemonic power that far exceeds that of humans," largely because places "outlast" the lives of individuals and carry forms of memory that transcend time and generation. Edward Casey even argues that we should view "memory [as] naturally place-oriented or at least place-supported." ${ }^{26}$ Places — and objects—serve to trigger memory, especially when human loss and silence define the experience of trauma, and when there is no one left to provide a survivor or eye-witness account.

The memory-oriented work of Brito and Pujol emerged during what Campa described as a "testimonial moment" in the lives of the second generation, for it was during the 1990s that members of this generation began to speak about their own losses with greater "intensity." 27 Importantly, the 1990s also witnessed a renewed exodus from Cuba by sea, following the earlier Mariel Boatlift of 1980. While an outpouring of film, theatre, literature and artwork about sea migration marked this decade in Cuba, in the United States, the return of the child immigrant to public view, this time in the guise of Elián González, whose custody battled in 1999 underscored the "politics of symbolic children" in US and Cuban foreign policy, triggered memories of Pedro Pan in a now adult exile generation. "We saw ourselves in him," declared Torres. During the 1990s, the second generation also began making return trips to Cuba in increasing numbers, against both US and Cuban restrictions, in order to restore and maintain family ties. Meanwhile, the new Cuban immigrants of the 1990s intensified transnational economic ties with Cuba by sending remittances to the island. ${ }^{28}$ Behind the individual case of Elián González, however, lay a period of collective trauma in Cuban history - the balsero crisis of the 1990s.

In this context, and in direct response to the balsero crisis, Alberto Rey's work took shape. Like the artists Brito and Pujol, and the writer-scholars Torres and Campa, Rey also experienced a "testimonial moment." Rey was not a child of Pedro Pan. Yet, born in Havana 
in 1960 and arriving in the United States via Mexico in 1964, he experienced similar "voids" associated with the memory of absence. From the 1980s onwards, Rey's relatives also attempted to make the same journey to the United States, this time by crossing the Florida Straits. Some never arrived. Whereas Brito and Pujol looked to the domestic spaces and memories of Cuban childhood, Rey looked towards the sea, and to the memory of others who arrived after him, mapping the human losses of the balsero crisis onto his own family's fragmentation. Rey's work suggests how Cuban American artists have used distinct languages of trauma associated with the aesthetics of disappearance to forge an extended memory among very different generations of Cuban exiles and migrants.

\section{The memory of absence in the early work of Alberto Rey}

Alberto Rey was born in Havana, Cuba, in 1960. He was raised in the village of Agramonte, from where his parents originated and the family owned a farm. After Rey's father was imprisoned for opposing Castro's rule, the family left Cuba in 1963 in search of political asylum in Mexico. In 1964, the Rey family moved to Miami and then, in 1967, to Barnesboro, an old mining town in Pennsylvania. Rey recalls spending most summers between 1968 and 1978 with family in Miami's Cuban community, visits that partially undermined the isolation of living in Barnesboro, where, as he remembers, the Reys "were the only Cubans around." Rey and his family were the first to depart Cuba, leaving behind his mother's parents and brothers, and his father's parents and siblings. While several of his father's siblings later arrived in the United States, his grandmother died at sea trying to leave Cuba during the Mariel Boatlift of 1980, and his uncle on his mother's side died a political prisoner in an agricultural camp in Cuba. ${ }^{29}$ With developing interests in both art and biology at college, Rey went on to complete his fine art training at Indiana University of Pennsylvania and the University of Buffalo, New York. After travelling to Boston, Miami, Spain, Italy, Morocco and Mexico, Rey took a 
teaching post in 1989 at the State University of New York at Fredonia, where he remains to this day as Distinguished Professor for Research and Creative Activity. Rey's works are in numerous permanent collections, including those of the Albright-Knox Museum, Buffalo; El Museo del Barrio, Bronx Museum of the Arts, and Brooklyn Museum in New York; Lowe Art Museum, University of Miami; Museum of Art, Fort Lauderdale; and Tampa Museum of Art. ${ }^{30}$ His artwork and testimony have appeared in several important volumes on Cuban American culture and memory, and he has most recently been the subject of a book and exhibition, entitled Life Streams: Alberto Rey's Cuban and American Art (2014), which is set to travel from the Burchfield Penney Art Center in Buffalo, New York. ${ }^{31}$

In existing scholarship, Rey's work is generally interpreted within the framework of Cuban exilic memory and second generation consciousness. Rey is part of a generation of "Cubands," a term used by Andrea O'Reilly Herrera to describe the sons and daughters of exiles born or raised in the United States who share their parents" "consciousness of exile." As Isabel Alvarez Borland notes, members of this generation "have had to create their stories from the void of absence," since Cuba is accessed only through the memories of their exiled parents. ${ }^{32}$ For Rey, who grew up outside Miami’s Cuban community, the experience of rupture and loss was even greater.

By the age of twenty-five, Rey had moved sixteen times. Place, memory and dislocation have remained constant themes in his work since the early Floating (1985-86) and Autogeographical (1985-87) mixed-media painting series, in which aerial views and layered landscapes invoke the multiple places that Rey has lived in both the United States and Cuba. In associating his work with spatial narratives and storytelling, Rey described "each painting ... [as] a visual novel," a "map" that enabled him to "find a sense of 'home' or 'identity"."33 In this period, Rey moved towards more abstract forms in order to articulate the emotional landscape of his dislocation. In his retreat from realism, Rey sought to express what he called 
"the spiritualness of memory and emotion." "I think realism and specific imagery create screens that make it difficult to experience the work emotionally," he explained. ${ }^{34}$ The overlapping configurations and spectral-like objects that appear in Rey's Binary Forms series (1990-92) (Figure 1) reference the complex layering of memory and the inadequacy of realist modes for communicating the losses of exile and family fragmentation: Rey entitles each painting/object number by number. The dislocation, spectrality and imperceptibility that mark these early works reappear in Rey's later series about traumatic memory, Las Balsas (199599). Rey's experimentation in these early works underscores his struggle to find a language with which to communicate an affective memory that might "connect with the viewer." This struggle saw Rey shifting back and forth between realism and abstraction in what he has since described as a "cyclical" movement, one that mirrors how trauma is rarely expressed within a singular formal framework or linear narrative. ${ }^{35}$

The difficulty of articulating the unspeakable also became manifest in Rey's experimentation with landscape painting. In negotiating Cuba's difficult socio-political past, Rey felt compelled "to get immersed in the country's landscape." As his fascination with the natural landscape developed, Rey reconnected with a Cuba that he had little memory of. However, his early experiments with landscape painting sought to bypass the traumatic memory of Cuba's difficult political past rather than attempt to work through it. As Rey explained, "I wanted to find a connection to this country in the purest manner without people or politics [my emphasis]." ${ }^{36}$ Rey's initial forays into landscape painting recreated Cuba as a romanticized place suspended in a pre-Revolutionary era. For example, the series Appropriated Memories (1995-97) reworks late nineteenth- and early twentieth-century photographs of Cuba in shadowy black-and-white and blue-and-grey tones so that the island becomes an evocative, nostalgic place untouched by time, power and disorder. Rey's tonal experimentation underscored his physical separation from the island, and from the political past and present. As 
Rey explained of his painting from the series, Viñales, Cuba, "with my brush, I almost felt as if I was walking through these [tobacco] fields, and since I hadn't been there before, this was as close as I had felt to being in Cuba." 37 These paintings were in many ways built upon other people's — namely other artist's - renderings and memories of Cuba. Rey's determination to resist the "political baggage" of Cuban revolution and exile was tied to an explicit strategy of creating images that were "just about the beauty of the landscape," as Rey explained of his Madonnas in Time (1993-95), which couples images of Cuba from the 1910s and 1920s with present-day landscapes of the United States (Figure 2). Echoing the ways in which Torres described memory as a "militarized zone," Rey claimed that the "political complexities that have clouded any image or story that has occurred during [his] lifetime" made it "difficult to discover the aesthetic importance of the country," and to speak about loss. ${ }^{38}$ While the nostalgic imagery of Appropriated Memories avoids a direct confrontation with the pain and fragmentation that appears in Rey's later works, the strategy of "appropriating" the memories — and the objects and artworks — of others, and tying these to his own memories, would continue to inform Rey's work as he explored the terrain of a broader "community" affected by loss.

In many ways, the mid-1990s constituted a turning point for Rey in terms of finding a language with which to speak about traumatic memory. In the same year as Appropriated Memories, Rey shifted his landscape painting away from nostalgic visions of the island and terra firma, and towards the space in between nations, namely the sea between the United States and Cuba. Rey has described "that little strait between Cuba and the United States [as] full of suffering and full of stories which will never be documented." 39 Since the 1960 s, the ninety-mile Florida Straits has remained the main migration route for Cubans leaving the island. It is this landscape — one marked by traces of human passage and loss and described by scholar Isabel Alvarez Borland as the scene of an "ocean holocaust" - that features in Rey's 
Las Balsas series. Borland describes the series as Rey's “most significant work on identity and community." In Las Balsas, the artist first "began a meditation on death" that continues to underpin his most recent, environmentally-focussed work. ${ }^{40}$ Far less nostalgic and more emblematic of his deterritorialized condition as a Cuband with little memory of the homeland, Rey's seascapes build on a tradition in Cuban and Cuban American art of depicting the ocean as a place of possibility, tragedy and diasporic identity. Cuban artists on both sides of the Florida Straits have explored the sea as a "traumatized region." ${ }^{41}$ The paintings by exiled Cuban artist Juan González, Mar de Lágrimas (Sea of Tears, 1987-88) and Free Fall (1993), depict human bodies dropping to the bottom of the ocean. Meanwhile, in the installations of Cuban artist Sandra Ramos from the series No Vida de Cabe en Una Maleta (Life Does Not Fit in a Suitcase, 1995-96) and Migraciones II (1994), suitcases become watery graves filled with drowned bodies, severed limbs, and abandoned objects.

\section{Los balseros and Cuban migration}

These depictions of a wounded ocean from the 1980s and 1990s reflect the intensification of undocumented sea migration from Cuba across the Florida Straits, a migration that resulted in the balsero (rafter) crisis of 1994. Cuban migration by boat and makeshift rafts called balsas increased during the 1990s when Cuba's economy was badly affected by the collapse of the Soviet Union. While Cubans had been leaving the island by boat since the 1960s, and most dramatically during the 1980 Mariel Boatlift, these numbers increased amidst the deteriorating economic conditions and political suppression of Cuba's "Special Period" during the 1990s. When Castro lifted the ban on Cubans departing by sea after protests broke out in Havana in 1994, more than 30,000 Cubans left the island that summer. Some hired costly smugglers and water taxis to get across the ocean; others left on boats with small motors while some escaped on makeshift rafts that made the already dangerous journey even more perilous. Most of those 
who left by boat were young people between the ages of twenty and twenty-nine, according to Holly Ackerman. In response, Cuban exiles in Miami established Los Hermanos al Rescate (Brothers to the Rescue), to search for balseros out at sea. The US Coast Guard rescued 45,575 rafters between 1991 and 1994, and 21,300 rafters alone in the month of August 1994. Of those rescued by the US Coast Guard between 1991 and 1994, 16,778 were detained in camps in Guantánamo Bay, Panama and Cuba. Those detained at Guantánamo Bay were eventually granted entry into the United States in 1995. At the same time, under the Cuban Migration Agreement of 1996, which revised the 1966 Cuban Adjustment Act, the United States forged the "wet foot, dry foot" policy. This policy ruled that rafters intercepted at sea would be returned to Cuba while those who made it to land would be offered the chance to apply for permanent residency, a law that differentiates Cuban arrivals from migrants arriving from Haiti and the Dominican Republic to this day. More recently, Cubans have left the island by speed boat as boteros (boaters). ${ }^{42}$

Cuban American artist and writer Coco Fusco described the balsero crisis as Cuba's "greatest wound." ${ }^{43}$ Like Pedro Pan, the scars of the balsero crisis are tied to the unknown and the unspeakable. Lynette Bosch suggests that while some 96,000 balseros made it to Miami, the number of those who died at sea remains unknown. Political tensions have made it difficult to talk objectively about the balsero crisis, claims Campa, since "all sides continue to use balseros as political pawns," much as they did the children of Pedro Pan. Indeed, there was talk among Cuban exile leaders of relocating Cuban children detained at Guantánamo to foster homes in Puerto Rico. Moreover, cases such as the Elián González affair have made it difficult to acknowledge other contexts of Caribbean migration, in which arrivals to the United States have not been granted refugee status so easily. ${ }^{44}$ Scholar Holly Ackerman claimed that in comparison with the marielitos, many balseros she sought out were reluctant to be interviewed, and those who accepted, wanted to remain anonymous and be interviewed "alone." Speaking 
in 2004, survivor Guillermo Armas, who featured in Balseros, a 2002 documentary film about the crisis, explained that he wanted to "close that chapter in [his] life." "I suffered a lot," he added. "I lived it. And I don’t want to relive it over again." ${ }^{45}$ Oral testimony projects have attempted to document the perilous journeys of balseros, many of whom fled on makeshift rafts, without fresh water and food, and vulnerable to searing heat, sun exposure, storms and shark-infested waters. For example, anthropologist Elisabeth Campisi recently analysed the "collective trauma" of balseros detained at Guantánamo. ${ }^{46}$

Although Rey belongs to an earlier generation of Cuban exiles, he is part of this collective trauma: several of his family members arrived by boat and raft, and in 1980, Rey's grandmother, Mercedes Rey, drowned after her boat upturned en route to Florida from the port of Mariel. Mercedes' body was found off Key West and identified by her son, Rey's uncle, Manolo Rey. Although Alberto had no memories of his grandmother, he recalled how the story of her death was told—or rather not told: "My grandmother's death was rarely discussed. It was difficult for my father and his brothers. The motor on the boat exploded in the middle of the boat, Olo Yumi. All of the fifty-two passengers, who were crammed into the boat, moved to the back when the explosion happened and it capsized-ten died (including my grandmother) thirty-eight survived, and four were not found. Elsa, my aunt, was found but there were not enough life jackets. Many died from burns from the gasoline." ${ }^{47}$ His grandmother's death forced Rey to begin the process of documenting what had been lost by Cuban Americans across the generations. Rey's decision to create Las Balsas in memory of his grandmother occurred at a "testimonial moment" in the life of Cubands, as Rey began to explore his loss through the trauma of others, building a narrative from his own exile in the 1960s through to the marielitos of the 1980s and on to the balseros of the 1990s.

\footnotetext{
Alberto Rey's Las Balsas (1995-1999)
} 
Las Balsas was partly inspired by Rey's visit in 1995 to the Cuban Refugee Center on Stock Island, near Key West. "Moved by the sight of the rafts" in the Center's backyard, Rey felt compelled to record their "decaying remains." For Rey, the balsas recovered by the Center resonated with the passing of his grandmother, and as a testimony designed to record loss, his paintings stand as "the only documentation of those constructions." Rey's Las Balsas series consists of three-dimensional and two-dimensional artwork: four sculptures, "Balsas Constructions," which are replicas of rafts that Rey created from found objects; and twentyeight paintings, "Balsas Artifacts," which depict rafts and objects left behind on the journey, including compasses, watches, shoes, maps and religious images of the patroness of Cuba, La Caridad del Cobre (Our Lady of Charity) (Figure 3). Some of these objects were given to the Center by rafters who made it to shore; others were discovered inside rafts found abandoned and without signs of life. ${ }^{48}$

As Lynette Bosch and Isabel Alvarez Borland note, Rey's project builds on an existing tradition in Cuban and Cuban American art of using the balsero as a metaphor for loss and diasporic identity. ${ }^{49}$ In the visceral paintings of Cuban American artists Arturo Rodríguez and Luis Cruz Azaceta, both dating from the 1980s, we find geographies of violence and "abjection" in the image of the balsero adrift at sea. ${ }^{50}$ In Azaceta's The Crossing (1991), the severed head of a balsero, whose mouth remains open in horror, rests inside an inner tube while jagged waves in violent colours threaten to envelop the raft. In some of Azaceta's balsero canvases, the artist's expansive use of whiteness drains colour from the scene to invoke not simply the torment of the sea and natural elements, but the spectrality of place. These spaces of abjection bring us back to the work of Mendieta, Brito and Pujol, whose spaces of nature and domesticity respectively articulated the trauma of orphanhood and the deterritorialized subject. While some of Mendieta's earth-body sculptures in Iowa experimented with the transformative impact of water in the shape of a floating island-body, balsero-themed art, 
which dates from at least the 1980s, explored the sea more emphatically as a landscape of violence. Like Rey, Azaceta experimented with objecthood. In Balsero: La Casita 2 (Rafter: The Little House 2, 1993) and Ark (1994), photographs of the balsero experience and selfportraits of the artist are layered over the human subject, suggesting the multi-faceted nature of memory as the photographs rest like ritual objects in an altar-like display. ${ }^{51}$ The rafter's body is partially obscured by the starkness of the canvas in Azaceta's Ark (1994), and the motif of the screaming rafter suggests an eerie silence, perhaps expressing something akin to Mendieta's "sublimated rage." Yet, in his images, Rey removes the human body entirely, thus departing from a tradition in which the balsero as tormented and fragmented soul (Rodríguez), or with severed head (Azaceta) takes centre stage. Rey's work forges an alternative language of disappearance and trauma that shares affinities with the missing body found in Mendieta's sculptures and the displaced objects found in Brito and Pujol's installations. Rey's work plays on a strategy in which, to quote Jill Bennett, the body is "fugitive rather than figurative." 52

While Rey's work has been interpreted within a tradition of rafter art and literature by Bosch and Borland, it also differs in its language of trauma, focusing not on the human subject directly, but on the traces of the human subject through references to place and objecthood, thus connecting with Cuban American art about orphanhood and disappearance from the 1970s (Mendieta) through to the 1990s (Brito and Pujol). In using remnants to commemorate those who did not survive the journey, Rey’s work prefaced George Sánchez-Calderón's El Museo de los Balseros (1996), an installation exhibited at Franklin Furnace Gallery, New York, in which rafts and found objects were displayed on shelves and in cabinets. Sánchez-Calderón's exhibition paid tribute to exiled Cuban artist, Félix Gonzales-Torres, and the four Brothers to the Rescue who died when their planes were shot down at sea by the Cuban Air Force during a rescue mission. Reflecting on the importance of the museum, critic Mary Staniszewsk recalled that the furore over the Brothers' deaths in the US media, and the resulting diplomatic 
crisis between Cuba and the United States, undermined attempts to discuss the fates of those lost at sea. "There was something missing in ... [what] I saw," she declared. Conversely, El Museo was an attempt to draw attention to these absent presences in a way that "forced the viewer to bear witness," added Staniszewsk. ${ }^{53}$ Attempts to narrate these histories and contextualise them within a broader chronology have since shaped plans to build the Cuban Exile History Museum in Miami. The conservative Cuban exile politics that inform these attempts have problematized the narration of the balsero crisis and its accompanying trauma. Indeed, the in-progress website for the museum omits direct reference to the collective trauma of balseros, speaking of individual survivors, Guantánamo Bay as a "safe haven," and the work of Brothers to the Rescue in a triumphalist narrative that lauds the United States as a model of freedom. This narrative shares much in common with the official version of Pedro Pan, which as Torres notes, "casts the entire operation as a pain-free and fully successful humanitarian rescue mission," in which there was no room to explore trauma or ambiguity. Indeed, Torres' claim that "the language of politics would not allow us to speak of the pain of separation" helps us to understand responses to the balsero crisis, and Rey's attempt to forge an alternative language of trauma. ${ }^{54}$

\section{"Seeing in the Dark"}

Rey's work has focussed on what Mendieta herself described as a "confrontation with the void." ${ }^{, 55}$ Rey has often experimented with the notion of silence as a way of expressing a loss that cannot be spoken of in conventional ways. Rey had no memories of his grandmother who died at sea, nor of his grandfather on his mother's side, who died of cancer in Cuba in 1978. Rey remembers his mother waiting to hear the news of his grandfather's death from Cuba, and a candle, burning in the darkened house at the time, strangely going out just before the family received the call. "No one seemed surprised and it was never discussed," added Rey. Similarly, 
when Rey returned to Cuba for the first time since his exile in 1998, he asked questions of his Cuban family, but remembers relatives speaking only about the time before he left. Recording these conversations in his documentary film Seeing in the Dark (2001), Rey explained: "It was as though I had no other life since that point." ${ }^{56}$ Rey had in some ways disappeared. For Rey, this memory of absence, and the absence of a language with which to speak about family loss, remained palpable. It is this absence that Rey attempts to communicate in Las Balsas. Indeed, Rey has called his Balsas paintings "silent remnants to great human tragedies," which simultaneously communicate the voids in his own life. ${ }^{57}$

These voids and silences are often expressed through remnants that function as memory objects. For Rey, who remembers all too well the journey in which he and other family members left with "literally the clothes on [their] back and one suitcase," objects exude a certain power through their physicality and solidity, a power that borders on the spiritual. Rey describes his paintings as "almost like permanent objects" that resemble "religious iconography": these "artifacts" in turn become "metaphors for experience." In Rey's work, the object matters most, for it carries memory and the power to bear witness to human loss. Rey explained that "each of these objects [in Las Balsas] are rich with stories of lives found, lost, and lives lived in Cuba." 58 Art historian Silvia Spitta has also spoken about the power of objects in Cuban American art to "mediate between the living and the dead." Works such as Rey's provide opportunities for the viewer to "think through the object."59

For Rey, objects can also forge "a connection to a sense of place" in the encounter with displacement. ${ }^{60}$ Dylan Trigg argues that "the spectrality of place," which often relies on the absence of the human body, "can fundamentally inform our understanding of traumatic memory." Art historian Marc Denaci has drawn attention to the "haunted aesthetics" and “absent presences" in Rey's larger body of work, which appear in Las Balsas and the ongoing series, The Aesthetics of Death (2006-). ${ }^{61}$ Rey's objects evoke a sense of loss through their 
spectral-like appearance. For example, in Balsas XII (Figure 4), the raft becomes a disembodied form "floating in a dark sea of black," to quote Rey. Illuminated by the same grey-blue-black tones that appear in Appropriated Memories, these abandoned vessels "glow" like apparitions emerging from the water. ${ }^{62}$ Rey's still life paintings of found objects are also stripped of context and bathed in shadowy light. In Balsas Artifacts: Compasses and Watch (Figure 5), the objects pushed to the corners of the canvas are barely discernible as the compass radiates light outwards as a symbol of both hope and despair. Thus, while Rey's use of light and realism appears to bring these objects out of the shadows, their obvious forms are simultaneously obscured as a way of articulating the difficulty in communicating traumatic memory. In the equally shadowy Map over Binoculars (Figure 6), we struggle to distinguish the space of the Florida Straits on a map that is torn, partly folded underneath itself, and partially illuminated. The land masses of Cuba and the United States become spectral-like forms, ghostly traces akin to the outlined map found in Ernesto Pujol's installation, The Children of Peter Pan. More importantly, a set of binoculars lies beneath the map, according to the painting's title. Again, Rey emphasises the struggle to see and to comprehend. Rey's language of trauma is neatly summed up by the title of one of his later documentary films, Seeing in the Dark (2001), in which Rey attempts to narrate his first trip back to Cuba in 1998 after more than thirty years in exile. Seeing in the Dark captures Cuba's landscape and inhabitants through the lens of a grainy black-and-white film, which is reminiscent of Rey's earlier, nostalgic hue in Appropriated Memories. As if to suggest the incompleteness of filmic representation, the documentary cuts periodically to lines of text-Rey's written testimonyand is overlaid with Cuban songs of loss, nostalgia and childhood. Text, image and music jar with one another in certain places, suggesting that multiple forms and genres are needed to piece together the fragments of memory, even as these same fragments resist being shaped into a fully cohesive or linear narrative. ${ }^{63}$ 
These multiple forms are also evident in Las Balsas. Rey's paintings transcend the space of the canvas to become fully-fledged objects and houses of memory in themselves. Some paintings are framed; others are encased in wooden boxes stained with black and red pigments so that they simulate coffins and the ways in which boxes have traditionally been used to store objects as carriers of memory (Figure 7). Rey describes these pieces as "minimal altar pieces" in which the objects, and the missing, can finally "rest." ${ }^{\text {"64 }}$ Rey's later series, Studio Retablos (1998-2000), which directly followed Las Balsas, involved the artist extending his fascination with accumulating found objects as carriers of intergenerational memory and mediators between the living and the dead. In collecting and revising "paintings that had been left behind in garbage cans, thrift stores or estate sales," Rey found himself engaging with "a history that had been abandoned," and with artists who had come before him, as he "removed layers of their paintings." He added: "I felt a strange connection to the work and to the unknown artists. These paintings found a home in a corner of my studio." ${ }^{95}$ Rey's experimentation with found objects has expressed an underlying desire to forge an intergenerational memory of loss. This strategy is also tied to the act of repetition and to what Ernesto Pujol has called "obsessive memory."

In Rey's paintings, the raft as a displaced, spectral symbol is repeated almost in a Pop art-like fashion, with Rey giving each painting only a number as a title. Marianne Hirsch has spoken of the tendency towards acts of repetition among the "postmemorial generation" of the Holocaust, suggesting that these modes of remembrance do not necessarily "retraumatize" subjects, but rather function as a way to productively "work through" the past. Likewise, Jill Bennett's analysis of trauma in contemporary art suggests that acts of repetition "may be understood as functioning in a regenerative way." Rey’s postmemory works on a similar level, by triggering a form of sense memory in the viewer through processes that Bennett calls "affective connection" and "embodied perception." 66 This sense memory is activated through 
the misplacement of found objects. Rey's focus on what appear to be mundane items — watches, sunglasses, hats, shoes, keys and cans of food-underscores the capacity of trauma and grief to seep into everyday life. The act of viewing a baby's bottle and children's shoes secreted inside an abandoned raft and outside their usual context (Figure 8), works to "defamiliarize" these objects and induce a mode of seeing associated with the fragmentation of loss and the disorientation of grief. Rey transforms these objects through his use of repetition, juxtaposition, and a compositional format that, by playing with the spectrality of light, distorts the very form and nature of the found object. In Rey's works, we struggle to see the objects while also experiencing the jarring sensation of seeing them all too clearly-as objects that are out of context and tied to some violent process that has thrown them out of place. Bennett suggests that representations of traumatic memory in contemporary art succeed primarily through "their capacity to engage the body of a viewer." ${ }^{, 67}$ In Las Balsas, Rey becomes a secondary witness whose work enacts an affective memory of grief that can be experienced by the viewer.

Rey's boxes of memory go beyond the simple act of commemoration by encouraging the viewer to become a secondary witness and storyteller. "If you eliminate the body from the composition," explained Rey, "then the viewer can feel like they can be in that composition, as a participant." ${ }^{\prime 68}$ While the brutal realities of human loss determine the removal of the human body from Rey's paintings, this removal also facilitates the viewer's active role as potential witness. In the process of memory work, Trigg suggests that ruins can "assume an aesthetic presence, inviting the viewer to fill out the broken form through the active dynamism of the imagination." As the "embodiment of disappearance," ruins enable us to communicate something of traumatic memory when other strategies of witnessing fail, especially written forms of testimony in which the narrative is often littered with disruptions, echoes and omissions as a result of trauma. Rey has spoken explicitly of his desire to "describe the indescribable." ${ }^{69}$ In Las Balsas, the disorientating effect of seeing objects out of place generates 
a series of questions about the missing person's narrative. According to Borland, Rey's strategy of removing key information through the rather dispassionate titles of the paintings - lists of found objects or numbers of paintings, such as Balsas XII — intensifies this effect, as does Rey's experimentation with darkness and illumination. Rey explained that he used the qualities of matte varnish in Las Balsas to entice the viewer into the image (whereas gloss is used in his more recent paintings to create a barrier between the art object and the viewer). The paintings in Las Balsas are also small, approximately four by five inches, which was a conscious device since Rey "wanted them to be very intimate."70

The participatory strategies at work in Las Balsas underscore Rey's desire to generate a form of secondary witnessing and dialogue. Yet if Rey's experimentation with affective memory breaks the silence about the individual and collective wounds of the balsero crisis, it also recognises the often incomprehensible and disorientating nature of trauma. A similar participatory strategy built on affect characterizes Rey's subsequent black-and-white documentary, Waters off Caibarién (2004), an hour-long loop that captures the eastern coast of Cuba where many rafters begin their journey to the United States. As a mode of secondary witnessing, Rey wanted to "actually be on that stretch of water," and generate for the viewer a sense of what rafters experienced on their perilous journeys, namely, an endless seascape "for days at a time." 71 In Rey's documentary, the repetitive motion of the film invokes the disorientating realities of a journey that sometimes induced a hallucinatory state in balseros who floated for days on end without sight of land.

In his earlier series, Rey struggled to convey what he called "the spiritualness of memory." If objects possess the ability to communicate the fragmented, disorientating nature of traumatic memory, Rey's experimentation with the form and spiritual qualities of devotional art provides a way of transmitting affective memory when conventional modes of testimony and realism fall short. Rey's early shift away from drawings that were "cluttered" with layered 
forms constituted part of his attempt to express "the emotional content of the work," what he also called "the spirituality of the work." 72 In a similar way, Rey has described his Balsas paintings and boxes as "minimal altar pieces." Through the practice of altar-making in particular, Rey brings everyday objects, spirituality and memory together. Rey's deep fascination with religious art forms permeates much of his work. In his earlier series, Madonnas of Western New York (1991-93), Madonnas in Time (1993-95), and Icons (1993-95), Rey blended images of Cuba with New York by experimenting with Mexican retablos or ex-votos (votive offerings that are either painted or in object form). In his depiction of everyday items, Rey became aware that "the more mundane they were," the more "they seemed to have this kind of sense of minimalism." Within this minimalism, Rey found what he called "a kind of spirituality." Rey completed the Balsas paintings on plaster panels to mimic the qualities of religious fresco art and has likened these paintings to retablos. ${ }^{73}$ In Mexican retablos, the artist gives thanks to a Catholic saint by inscribing a dedication on the canvas or material on which the retablo is painted, thus telling the story. In lieu of the lost balsero's narrative, Rey inscribes his own testimony, by pencilling the dates on which he worked on the canvas in the top lefthand corner of each painting. Objects can forge a connection between the past and the present and between those alive and those lost to us, in much the same way that ex-votos perform an expression of faith and testimony for others who later witness the piece and the narrative that it embodies. Rey's objects, like spiritual icons, embody the possibility of both mourning and healing.

Rey's displacement enabled him to turn his art into something cathartic. In using art to "create this connection to the culture and to things that have been lost," Las Balsas became Rey's "way of making peace" with family loss. The series initiated a process of personal healing for Rey, who described his Cuban-inspired paintings more broadly as facilitating "a cleansing" that helped him to create a "more unified" body of work. In his "confrontation with 
the void," Rey added, "I think that void will always be there, but it's much smaller." ${ }^{74}$ If Las Balsas marked a transition in Rey's oeuvre away from nostalgic visions of Cuba, it also initiated a process of building bridges to Cuba. ${ }^{75}$ In 1998, while completing Las Balsas, Rey returned to Cuba for the first time. While Rey described these visits as "emotionally draining," they also produced two black-and-white films, Seeing in the Dark (2001) and An Unkept Promise (2005), both of which contemplate not the mythical homeland of the first generation, but an island of conflict and living people who are imbued with strength and resilience. ${ }^{76}$ In Cuban Portraits (1998-99), which followed Las Balsas, Rey began integrating human subjects and members of his own family into his paintings for the first time, and into the spaces where there had been only absence. If Rey's Cuban Portraits became "a tribute" to those who remained in Cuba, they were also a symbolic means of uniting the Cuban family across the Florida Straits. Rey depicts individuals from both Miami, Florida, and Agramonte, Cuba, the place where he was raised, and as Bosch notes, he also depicts two "Albertos" in the series, one from Miami and the other from Agramonte, as an attempt to heal the divided self and work through the fragmentation of the individual and collective Cuban family. ${ }^{77}$

In Rey's art we find overlapping testimonies of trauma and intergenerational memory. While these testimonies attempt to communicate the pain of loss and disappearance, they also express a desire to create something new by establishing links between different generations affected by trauma. Indeed, if we consider Rey's series as embedded in a wider chronology, and in the context of subsequent Cuban migrations to the United States, from the marielitos to the balseros and boteros, we see how second generation Cubands such as Rey build their memories and bridges to Cuba through the stories of those who came after them, as well as through the "appropriated memories" of a first generation on both sides of the Florida Straits. Rey's Balsas paintings help to construct an autobiographical and family testimony. But if Las Balsas speaks of Rey's grandmother and a lost Cuba, it also functions as a broader collective 
testimony. The elements of repetition in Rey's Balsas paintings - the numbers and lists of objects in the titles_-invoke repeated trauma and loss, thus moving from what Borland calls "a process of [individual] grieving"- Rey's own — towards a collective mode of bearing witness and "communal mourning." In building this community of mourning, Borland focusses largely on Rey's use of the raft as "a pervasive icon of exile" in art and literature, which unites Cubans across the generations. ${ }^{78}$ However, it is not so much the motif of the raft, which is sometimes absent in Rey's paintings, but rather Rey's language of trauma and his use of affective memory that structure this broader community. Indeed, the performance of disappearance, recollection and remembrance that takes place in Las Balsas, principally through the found object, connects Rey and his memory work to different time periods and traumatic events, to artists from the Pedro Pan generation, and finally, to art created about the balseros from the 1990s through to the present day.

\section{Los balseros in recent Cuban American art}

Rey's series connects with the visual languages of trauma that have appeared in more recent installation and performance works about balseros. In Pero Sin Amo (Without a Master, 19992000), María Brito extends her tradition of experimental assemblage to commemorate those lost at sea. Brito's installation is constructed from wooden boxes akin to coffins in which rest found objects - shoes, spectacles, and the remnants of body parts. The boxes are brought together in the shape of a labyrinth so that the viewer can move through them and peer inside. ${ }^{79}$ However, Brito's objects, much like Rey's, are partially obscured; for example, a shoe, overlaid with sand, lies sideways in a box within a box so that its form is disfigured. Meanwhile, Brito installs two look-out points at each end of the installation, both with sets of binoculars through which we cannot see since the lenses are covered. While Brito's installation invites the viewer to witness the losses of human migration, it stops short of allowing us to see everything clearly, 
mirroring the way that Rey deliberately obscures the act of vision in his painting Map over Binoculars. Like Rey, Brito suggests how Cuban migration has become enmeshed in the "militarized zone" of memory, and how the unspeakable facets of traumatic memory can perhaps never be fully translated.

Yet this does not mean that elements of reconciliation and healing fade from view entirely. In the exhibition Exodus: Alternate Documents: An Artistic Project for the Recovery of Collective Memory (2014), by the Aluna Curatorial Collective at CCEMiami (Centro Cultural Español de Miami), Cuban American artists collaborated with Miami-based balsero survivors to commemorate the twentieth anniversary of the balsero crisis. Coco Fusco's video installation-performance, $Y$ entonces el mar te habla (And The Sea Will Talk to You, 2012), encouraged viewers to remove their possessions and seat themselves on inner tubes before a film screen on which images of the Caribbean sea were overlaid with the poetry and narratives of those who have crossed the Florida Straits. ${ }^{80}$ Fusco's multi-media installation employed different genres to communicate a fragmented traumatic memory and trigger a sense of disorientation in the viewer. Importantly, in Fusco's multi-authored film narrative, we encounter a Cuban American woman transporting her mother's ashes back to Cuba from the United States, in what becomes another "illegal" crossing, this time in reverse. Yet it is the spiritually-endowed object in which the mother's ashes are concealed-a prenda, a ritual cauldron associated with Cuban Santería and Palo, which contains earth, sticks, and bones and is blessed by a priest - that enables the safe passage of the ashes back to home, and in turn, the building of bridges between the living and the dead, and Cuba and the United States. ${ }^{81}$ In this way, as in Rey's Las Balsas, the performance of grief and loss through spiritually-endowed memory objects initiates a process of healing rather than retraumatization.

\section{Conclusion}


When Ana Mendieta wrote the poetic statement "Pain of Cuba / body I am," she did so in the belief that her sculptures were in direct "confrontation with the void." 82 The work of Alberto Rey also interrogates this memory of absence, negotiating the ways in which Cuban diasporic memory has become a "militarized zone," distorted by political conflict, triumphalist narratives of freedom and heroism, and fractured by the trauma of different generations of exiles and immigrants. Placed in dialogue with works by other "Cuband" artists and with other traumatic events from Operation Pedro Pan through to the balsero crisis, Rey's language of trauma becomes part of an extended memory tied to the aesthetics of disappearance and remembrance in contemporary Cuban American art. By playing on the missing body and the misplacement of objects found along the wounded migration route of the Florida Straits, Rey's visual language provides the basis for a collective, intergenerational memory of trauma through which the past and the present, the living and the dead, can coexist. Rey's visual language provides a way of "seeing in the dark," while at the same time acknowledging the fragmented and disorientating realities of grief and trauma. The emphasis on objects as powerful memory texts in Rey's Las Balsas, and the interplay between autobiographical, family and intergenerational testimonies of migration and exile suggest how visual artists can provide us with more collective, participatory and redemptive models of memory work.

\footnotetext{
${ }^{1}$ Cathy Caruth, Unclaimed Experience: Trauma, Narrative, and History (Baltimore: Johns Hopkins University Press, 1996), 91-92.

${ }^{2}$ Caruth, Unclaimed Experience, 7, 11; Jill Bennett, “Art, Affect, and the 'Bad Death': Strategies for Communicating the Sense Memory of Loss," Signs: Journal of Women in Culture and Society Volume 28, No 1 (2002), 339.

${ }^{3}$ Alberto Rey, interview with Jorge J. E. Gracia, 21 May 2005, accessed 6 June 2014, http://www.buffalo.edu/cas/philosophy/faculty/faculty_directory/gracia/capen/CubanArt/_jcr_content/par/downl oad_22/file.res/iRey.html.
} 
${ }^{4}$ Diana Taylor, The Archive and the Repertoire: Performing Cultural Memory in the Americas (Durham: Duke University Press, 2003).

${ }^{5}$ For example, see Peggy Phelan, Unmarked: The Politics of Performance (New York: Routledge, 1993); Karen E. Till, “Artistic and Activist Memory-Work: Approaching Place-Based Practice,” Memory Studies Volume 1, No1 (2008), 99-113; Lisa Saltzman, Making Memory Matter: Strategies of Remembrance in Contemporary Art (Chicago: University of Chicago Press, 2006); Jill Bennett, Empathic Vision: Affect, Trauma, and Contemporary Art (Stanford: Stanford University Press, 2005); and Marianne Hirsch, The Generation of Postmemory: Writing and Visual Culture After the Holocaust (New York: Columbia University Press, 2012).

${ }^{6}$ Bennett, "Art, Affect," 347, 342-48.

${ }^{7}$ Here, I employ the term used by art historian Jane Blocker in connection with Cuban American artist Ana Mendieta. See Jane Blocker, Where is Ana Mendieta? Identity, Performativity, and Exile (Durham: Duke University Press, 1999), 18.

${ }^{8}$ Bennett, “Art, Affect," 339-50; Bennett, Empathic Vision, 11.

${ }^{9}$ For example, see “Appropriated Memories—A Conversation with Alberto Rey: Interview conducted by Andrea O'Reilly Herrera, March 1997 and September 1998," in ReMembering Cuba: Legacy of a Diaspora, ed. Andrea O'Reilly Herrera (Austin: University of Texas Press, 2001), 299-306; Andrea O’Reilly Herrera, “The Consciousness of Exile: Memory and Vicarious Imagination in Cuban-American Literature and Art, Journal of West Indian Literature Volume 8, No 1 (1998), 82-98; Isabel Alvarez Borland, "The Memories of Others: Ana Menéndez and Alberto Rey," Review: Literature and Arts of the Americas Volume 42, No 1 (2009), 11-20; Alberto Rey, "Landscapes of the Mind," in Identity, Memory, and Diaspora: Voices of Cuban-American Artists, Writers, and Philosophers, eds., Jorge Gracia, Lynette Bosch, and Isabel Alvarez Borland (Albany: State University of New York Press), 91-101; Lynette Bosch and Marc Denaci, eds., Life Streams: Alberto Rey's Cuban and American Art (Albany: State University of New York Press, 2014).

${ }^{10}$ Román de la Campa, Cuba on My Mind: Journeys to a Severed Nation (London: Verso, 2000), 80.

${ }^{11}$ María de los Angeles Torres, In The Land of Mirrors: Cuban Exile Politics in the United States (Ann Arbor: Michigan University Press, 2001), 10.

${ }^{12}$ Olga Viso, "Foreword and Acknowledgements," Transcending the Borders of Memory (West Palm Beach, Florida: Norton Gallery of Art, 1994), 1-2. 
${ }^{13}$ Cris Hassold, accompanying essay in Remnants: Installations by Five Cuban American Artists-María Brito, Pablo Cano, María Emilia Castagliola, María Elena González, Mario Petrirena, exhibition catalogue, 10 Sept.—24 Oct. 1993, Shillard Smith Gallery, 1.

${ }^{14}$ Ricardo L Ortíz, Cultural Erotics in Cuban America (Minneapolis: University of Minnesota Press, 2007 ), 8.

${ }^{15}$ Karen Dubinsky, "Cuba's Monumental Children: Operation Peter Pan and the Intimacies of Foreign Policy," in Catherine Krull, ed., Cuba in a Global Context: International Relations, Internationalism and

Transnationalism (Gainesville: University Press of Florida, 2014), 59-60.

${ }^{16}$ Ana Mendieta quoted in Charles Merewether, "From Inscription to Dissolution: An Essay on Expenditure in the Work of Ana Mendieta," in Corpus Delecti: Performance Art of the Americas, ed. Coco Fusco (London: Routledge, 2000), 139.

${ }^{17}$ Blocker, Where is Ana Mendieta? 18, 23, 30; Peggy Phelan quoted in Blocker, Where is Ana Mendieta? 109.

${ }^{18}$ Ana Mendieta, interview with Linda Montano, Sulfur Volume 22 (1988), 66.

${ }^{19}$ On Brito's work and these installations in particular, see Juan A. Martínez, María Brito (Los Angeles: UCLA Chicano Studies Research Center Press, 2009), 7, 25.

${ }^{20}$ Brito quoted in Martínez, María Brito, 7.

${ }^{21}$ Dubinsky, “Cuba's Monumental Children,” 59, 72.

${ }^{22}$ Campa, Cuba on My Mind, 43. Also see Dubinsky, “Cuba’s Monumental Children,” 66-69, 72.

${ }^{23}$ María de los Angeles Torres, The Lost Apple: Operation Pedro Pan, Cuban Children in the US, and the Promise of a Better Future (Boston: Beacon Press, 2003), 10; Mendieta in conversation with Eva Cockcroft, in Eva Cockcroft, “Culture and Survival,” Art and Artists Volume 12, No 3 (1983), 16.

${ }^{24}$ On this installation, see Yolanda Wood, “Metaphors of a Journey,” Third Text Volume 9, No 31 (2008), 7173, and Laura Roulet, Contemporary Puerto Rican Installation Art: The Guagua Aérea, the Trojan Horse, and the Termite (San Juan, PR.: Editorial de la Universidad de Puerto Rico, 2000), 14-15.

${ }^{25}$ Ernesto Pujol, "The House Project," in Kim Kanatani and Denise Gay, Public + Artist Program (Los Angeles: Museum of Contemporary Art, 1995), 6-7; Ernesto Pujol quoted in "The Esthetics of Knowledge: A Conversation between David Henry and Ernesto Pujol," RISD Museum Exhibition Notes No 9 (Fall 1999), n.p., both in Ernesto Pujol files, vertical files, El Museo del Barrio, New York City.

${ }^{26}$ Aleida Assmann, Cultural Memory and Western Civilization: Functions, Media, Archives (New York: Cambridge University Press, 2011), 281-83; Edward Casey quoted in Dolores Hayden, The Power of Place: Urban Landscape as Public History (Cambridge, Mass.: MIT Press, 1995), 46. 
${ }^{27}$ Campa, Cuba on My Mind, 52-53.

${ }^{28}$ Dubinsky, "Cuba's Monumental Children," 69-71; Torres, The Lost Apple, 257; Susan Eckstein and Laura Barberia, "Grounding Immigrant Generations in History: Cuban Americans and Their Transnational Ties," International Migration Review Volume 36, No 3 (2002), 799-837.

${ }^{29}$ Rey quoted in "Biographical Timeline," in Bosch, Life Streams, 207-10.

30 “Appropriated Memories-A Conversation with Alberto Rey,” 300; Alberto Rey, "Biography,” Rey’s homepage, accessed 9 Jan. 2015, http://albertorey.com/bio/; Rey quoted in "Biographical Timeline," Life Streams, 210.

${ }^{31}$ For example, see “Appropriated Memories-A Conversation,” 299-306; Rey, "Landscapes of the Mind," 91101; Bosch, Life Streams.

${ }^{32}$ Herrera, ReMembering Cuba, xxix-xxx; Herrera, "The Consciousness of Exile," 82; Herrera, Cuban Artists Across the Diaspora: Setting the Tent Against the House (Austin: University of Texas Press, 2011), 7, 12-13, 32; Borland, "The Memories of Others," 11.

33 “Alberto Rey: Looking for a Home: 1985-2007," lecture by Alberto Rey at Washington and Lee University, YouTube, accessed 29 Jan. 2015, https://www.youtube.com/watch?v=IOFvna4_jYM; Rey, “Autogeographical and Floating Series: Artist Statement,” Rey's homepage, accessed 15 Sept. 2015; http://albertorey.com/paintings/artist-statements-on-earlier-series/autogeographical-and-floating-series/.

${ }^{34}$ Rey, "Binary Forms: Artist Statement,” Rey’s homepage, accessed 15 Sept. 2015, http://albertorey.com/paintings/artist-statements-on-earlier-series/binary-forms-series/; Rey, interview with Heather Gring, Burchfield Penney Art Center, State University of New York, Buffalo, for the "Living Legacy Project," undated, accessed 29 Jan. 2015, https://www.burchfieldpenney.org/artists/artist:alberto-rey/.

${ }^{35}$ Rey, "Binary Forms: Artist Statement"; Rey, interview with Gring.

${ }^{36}$ Alberto Rey, “Appropriated Memories: Artist Statement,” Rey’s homepage, accessed 9 Jan. 2015, http://albertorey.com/paintings/artist-statements-on-earlier-series/appropriated-memories/; Rey quoted in Herrera, "The Consciousness of Exile," 95; Rey, interview with Gring.

${ }^{37}$ Rey, “Appropriated Memories: Artist Statement"; Rey, interview with Gring.

${ }^{38}$ Rey, “Alberto Rey: Looking for a Home”; Rey, “Madonnas in Time: Artist Statement,” Rey’s homepage, accessed 15 Sept. 2015, http://albertorey.com/paintings/artist-statements-on-earlier-series/madonnas-in-timeseries/.

${ }^{39}$ Rey, interview with the author, 2 March 2015. 
${ }^{40}$ Borland, "The Memories of Others," 15; Isabel Alvarez Borland, “Alberto Rey's Balsas Series in the Cuban American Imagination,” in Bosch, Life Streams, 72.

${ }^{41}$ I employ Karen Till’s phraseology here. See Till, “Artistic and Activist Memory-Work,” 103.

${ }^{42}$ Felix Roberto Masud-Piloto, From Welcomed Exiles to Illegal Immigrants: Cuban Migration to the US, 1959 1995 (Lanham, MD.: Rowman and Littlefield, 1996), 136-39; Holly Ackerman, "The Balsero Phenomenon, 1991-1994," Cuban Studies Volume 26 (1996), 171, 179, 169.

${ }^{43}$ Coco Fusco, "Bridge Over Troubled Waters: And View From the Bridge Four Years On,” in Fusco, The Bodies That Were Not Ours and Other Writings (London: Routledge, 2001), 162.

${ }^{44}$ Lynette M. F. Bosch, Cuban-American Art in Miami: Exile, Identity, and the Neo-Baroque (Farnham, Surrey: Lund Humphries, 2004), 28; Campa, Cuba on my Mind, 50-52; Torres, The Lost Apple, 256-57.

${ }^{45}$ Ackerman, "The Balsero Phenomenon,” 188-89; Guillermo Armas, quoted in Daniel de Vise and Elane de Valle, "Cuban balseros Helped Change the Political Flavor of Florida," The Miami Herald, 3 Aug. 2004, accessed 14 Sept. 2015, http://www.cubanet.org/htdocs/CNews/y04/sep04/03e12.htm.

${ }^{46}$ For example, see “Beyond Fear: An Interview with Julio J. Guerra Molina, 1998,” in Herrera, ReMembering Cuba, 45; Elizabeth Campisi, “Guantánamo: Safe Haven or Traumatic Interlude?” Latino Studies Volume 3, No 3 (2005), 375-92.

${ }^{47}$ Rey quoted in "Biographical Timeline," in Life Streams, 208-13.

${ }^{48}$ Rey, interview with Gracia; Rey, interview with author.

${ }^{49}$ Lynette Bosch, "Introduction,” in Bosch, Life Streams, 1-11; Borland, “Alberto Rey’s Balsas Series,” in Bosch, Life Streams, 67-82.

${ }^{50}$ Chon Noriega, "Foreword," and Alejandro Anreus, both in Alejandro Anreus, Luis Cruz Azaceta (Los Angeles: UCLA Chicano Studies Research Center Press, 2014), x, 65-69.

${ }^{51}$ For these images, see Anreus, Luis Cruz Azaceta, 65-69. Also see Cruz Azaceta’s webpage, “Selected Works," accessed 5 March 2015, http://www.luiscruzazaceta.net/selected-works/category/76-prpints, and http://www.thefarbercollection.com/artists/luis_cruz_azaceta.

${ }^{52}$ Bennett, “Art, Affect," 336.

${ }^{53}$ George Sánchez-Calderón, “Museo de los Balseros,” accessed 10 June 2014, http://www.sanchezcalderon.com/GSC2012/Museo_Balseros.html; Mary Staniszewsk, "Museo de los Balseros at Franklin Furnace,” Artnet Magazine, no date, accessed 10 June 2014, http://www.artnet.com/magazine_pre2000/features/stan/stan4-2-96.asp. 
54 “Cuban Exile History Museum, Planned Exhibits,” 2015, accessed 30 Sept. 2015, http://cehmuseum.com/exhibits/; Torres, The Lost Apple, 17, 216.

${ }^{55}$ Ana Mendieta quoted in Olga Viso, Unseen Mendieta: The Unpublished Works of Ana Mendieta (Munich: Prestel Verlag, 2008), 293.

${ }^{56}$ Rey quoted in "Biographical Timeline," in Bosch, Life Streams, 211-13; Rey, "Seeing in the Dark (2001)," Rey's homepage, accessed 6 June 2014, http://albertorey.com/video-ar/seeing-in-the-dark/.

${ }^{57}$ Rey, “Las Balsas: Artist Statement,” Rey’s homepage, accessed 6 June 2014, http://albertorey.com/paintings/artist-statements-on-earlier-series/las-balsas-the-rafts/. Also see Rey, interview with Gracia; Herrera and Rey quoted in “Appropriated Memories," in Herrera, ReMembering Cuba, 304.

${ }^{58}$ Rey, interview with Gring; Rey, interview with author.

${ }^{59}$ Silvia Spitta, Misplaced Objects: Migrating Collections and Recollections in Europe and the Americas, (Austin: University of Texas Press, 2009), 17, 23.

${ }^{60}$ Rey, interview with author.

${ }^{61}$ Dylan Trigg, "The Place of Trauma: Memory, Hauntings, and the Temporality of Ruins," Memory Studies Volume 2, No 1 (2009), 88; Marc Denaci, “Absent Presences and the Living Dead: Alberto Rey’s Haunted Aesthetics," in Bosch, Life Streams, 83-103.

${ }^{62}$ Rey, interview with author. On the use of grisaille in Rey's work, see Bosch, Cuban-American Art, 142.

${ }^{63}$ Rey, "Seeing in the Dark."

${ }^{64}$ Rey, "Las Balsas: Artist Statement”; Rey, interview with Gracia.

${ }^{65}$ Rey, “Studio Retablos: Artist Statement,” Rey’s homepage, accessed 6 June 2014, http://albertorey.com/paintings/artist-statements-on-earlier-series/studio-retablos/.

${ }^{66}$ Marianne Hirsch, "Surviving Images: Holocaust Photographs and the Work of Postmemory," The Yale Journal of Criticism Volume 14, No 1 (2001), 9; Bennett, “Art, Affect," 339, 347, 350.

${ }^{67}$ Bennett, “Art, Affect,” 346-50.

${ }^{68}$ Rey, interview with author.

${ }^{69}$ Trigg, "The Place of Trauma," 88-89, 99; Rey, interview with Gracia.

${ }^{70}$ Borland, “Alberto Rey’s Balsas Series," 71-72; Rey, interview with Gracia; Rey, interview with Gring.

${ }^{71}$ Rey, interview with author.

${ }^{72}$ Rey, interview with Gring.

${ }^{73}$ Rey, “Alberto Rey: Looking for a Home”; Rey, interview with Gracia. 
${ }^{74}$ Rey, interview with author; Rey, interview with Gring; Rey, "Landscapes of the Mind," 96.

${ }^{75}$ The term "bridges to Cuba" also references Ruth Behar's influential edited collection of essays, testimonies, poetry and prose, Bridges to Cuba / Puentes a Cuba (Ann Arbor: University of Michigan Press, 1995), which featured writings by Cubans from Cuba and the diaspora. Behar's collaborative online blog project with Richard Blanco also takes the title of her anthology, and uses storytelling to "lift the emotional embargo" during a new period of US-Cuban détente. See Bridges To / From Cuba, accessed 4 Apr. 2016, http://bridgestocuba.com/about/.

${ }^{76}$ Rey, interview with author.

${ }^{77}$ Rey, interview with Gring; Bosch, Cuban-American Art, 145.

${ }^{78}$ Borland, “Alberto Rey’s Balsas Series,” 74, 81.

${ }^{79}$ For these images, see Martínez, María Brito, 48-50.

80 "Exodus: Alternate Documents," no date, accessed 10 Mar. 2015, http://www.alunartfoundation.com/exodusalternate-documents/; Coco Fusco, "Y entonces el mar te habla (2012)," accessed 10 Mar. 2015, http://cocofusco.com/.

${ }^{81}$ For a description of Fusco's film, see Colin Perry, “Coco Fusco’s And the Sea Will Talk to You,” 24 Sept. 2015, http://www.art-agenda.com/reviews/coco-fusco\%E2\%80\%99s-\%E2\%80\%9Cand-the-sea-will-talk-toyou\%E2\%80\%9D/. During the writing of this piece, Fusco's installation travelled to London where it was exhibited at Cecilia Brunson Projects and discussed in the context of the UK's own public debate about migrants who have arrived by sea.

${ }^{82}$ Mendieta quoted in Viso, Unseen Mendieta, 199, 293. 